\begin{tabular}{ccc}
\hline Bentham open & The Open Urology \& Nephrology \\
CrossMark & Cournal & Dol: $10.2174 / 1874303 X 01811010001$ \\
\hline
\end{tabular}

RESEARCH ARTICLE

\title{
Crossed Fused Ectopia of Kidney - An Account of Tertiary Healthcare Center Experience
}

\author{
BM Zeeshan Hameed, Arun Chawla*, Padmaraj Hegde and Tirth Vasa \\ Department of Urology, Kasturba Medical College, Manipal Academy of Higher Education, India
}

Received: October 10, 2017

Revised: March 10, 2018

Accepted: March 20, 2018

\begin{abstract}
:
Background:

Crossed renal ectopia with fusion is the abnormal migration of the kidney to the opposite side of the insertion of the ureter to the bladder. It is the second most common congenital anomaly of the kidney and urinary tract preceded by horseshoe kidney. The following article serves to highlight the anomaly in a conglomeration of 17 unique cases, managed in our tertiary care centre over a period of 5 years.
\end{abstract}

\section{Materials and Methods:}

This is a descriptive study analysing the demographic features and the management of seventeen patients diagnosed with crossed renal ectopia with fusion during the period January 2012 to January 2017. Radiological modalities of investigation were modified as per the anomaly. The management plan was devised keeping in mind, the essence of preserving the functional unit.

\section{Results:}

Of the seventeen cases, nine patients were symptomatic and eight were asymptomatic. The most recurring crossed renal ectopia with fusion was L- shaped $(n=6)$, disc shaped $(n=6)$ sigmoid shaped $(n=2)$, inferior $(n=1)$, cake shaped $(n=1)$ and superior ectopia $(n=1)$. Left to right ectopia $(n=9)$ was more common than right to left $(n=8)$. Three patients had a solitary crossed ectopia. Out of nine symptomatic patients, six patients underwent surgical procedures, the remaining three were treated conservatively and advised regular biannual follow-up with imaging.

\section{Conclusion:}

The management of crossed renal ectopia with fusion is individualised according to the underlying urological anomaly and its sequelae. Importance is given to preserve the renal function whenever possible. Reconstructive surgeries like pyeloplasty, ureteric reimplantation, boari flap can salvage some function in these units.

Keywords: Crossed renal ectopia, Renal anomaly, Fusion, Functional unit, Solitary renal ectopia, Atretic ureter.

\section{INTRODUCTION}

Crossed Renal Ectopia (CRE) with fusion is a rare congenital anomaly of kidney. It is the second most common fusion anomaly, after horseshoe kidney where kidneys do not cross each other. The incidence of CRE with fusion is around 1:3000 to 1:7500 [1]. Most cases of crossed renal ectopia with fusion remain asymptomatic and are diagnosed incidentally. There are few cases of crossed renal ectopia with fusion reported in the literature.

The management includes choosing appropriate imaging for the diagnosis of the type of fusion anomaly, the urinary tract abnormality and associated anomalies other than the urinary tract. The intervention is aimed at the preservation of

\footnotetext{
* Address correspondence to this author at the Department of Urology, Kasturba Medical College, Manipal Academy of Higher Education, India; Tel:+91- 9741970101; E-mail: Chawla.uroarun@gmail.com
} 
the renal function. However non-functioning units need surgical extirpation. We present nine different cases of CRE with fusion, which were managed in our institute for the last five years.

\section{MATERIALS AND METHODS}

The following study was done at a tertiary care centre, with the presence of a dedicated unit specialising in reconstructive urology. The duration of this study was between January 2012 to January 2017, for a period of five years. Of the total cases of CRE $(n=17)$, nine patients were symptomatic and eight were asymptomatic. Detailed history was taken and clinical examination was performed.

All the patients underwent renal function test with electrolytes, complete blood picture, urine microscopy, urine culture and sensitivity. Ultrasound (USG) of the abdomen and pelvis was done for all the patients. Depending on the presence of upper/lower urinary tract abnormalities, further radiological investigations comprised of Contrast enhanced Computed Tomography (CECT), Magnetic Resonance Imaging (MRI), Non Contrast CT (NCCT), Retrograde pyelogram (RGP), micturating cystourethrogram(MCU) and intravenous Urogram (IVU). Imaging procedures were tailored according to the type of the fusion anomaly and associated abnormality. In patient with USG features of hydronephrosis, IVU/ CECT abdomen and pelvis was done to rule out pelvi-ureteric junction obstruction. Patient having hydroureteronephrosis, MCU was done with a suspicion of vesico-ureteric reflux (VUR). NCCT was done to rule out stone disease. CECT was done to visualise the vascular anatomy and to facilitate the planning of intervention. Though aware of the aberrant and unusual vasculature, note was made regarding the course of the renal vessels to both the units by contrast based imaging $(n=11)$. In a pregnant lady, MRI was done to visualise the anomaly.

Management also consisted of interdepartmental consultations which included paediatrics, nephrology, paediatric surgery, neurosurgery, obstetrics and medicine were sought for existing non urological conditions. Interventional procedures $(\mathrm{N}=6)$ included nephroureterctomy $(\mathrm{n}=1)$ and a range of reconstructive procedures $(\mathrm{n}=3)$ like Anderson Hynes dismembered pyeloplasty, Cohen cross trigonal ureteric reimplantation, and Boari flap. Minimal invasive procedures $(n=2)$ like laparoscopy assisted percutaneous nephrolithotomy and double J stenting. Conservative and watchful management $(n=11)$ included antibiotics, analgesics and regular follow up with USG imaging. The patients were followed up duly, for a minimum of six-month post therapy.

\section{RESULTS}

Out of $\mathrm{N}=17$ patients of Crossed Renal Ectopia (CRE) with fusion, $\mathrm{n}=9$ were symptomatic and $\mathrm{n}=8$ were asymptomatic. Majority of them were male patients $(n=10)$, with the age span between 3 months to 50 years. Our clinical profile of CRE with fusion included asymptomatic $(n=8)$ as the most common finding. Among the symptomatic patients, the commonest symptom was pain abdomen $(n=5)$, followed by urinary tract infection ( $n=3)$, follow up of antenatal hydronephrosis $(n=1)$. One patient had impaired renal function with sepsis. One lady was pregnant with 30 weeks of gestation.

All patients had USG abdomen and pelvis as the initial imaging, followed by CECT $(n=11), \operatorname{NCCT}(n=4)$, MCU $(n=2), \operatorname{RGP}(n=2)$, IVU $(n=1), \operatorname{MRI}(n=1)$, Nephrostogram $(n=1)$. The most common crossed renal ectopia was the left to right fusion $(n=9)$, as compared to right to left CRE $(n=8)$. The most common fusion anomaly was L- shaped ( $n=6)$, disc shaped $(n=6)$ sigmoid shaped $(n=2)$, inferior $(n=1)$, cake shaped $(n=1)$ and superior ectopia $(n=1) . N=3$ patients had a solitary crossed ectopia with single ureter, which is very rare.

$\mathrm{N}=5$ patients had hydronephrosis on imaging and $\mathrm{n}=2$ had hydroureteronephrosis. Three patients with right to left fusion had an atretic left ureter. The associated non urological anomaly were hydrocephalous, Meckels diverticulum. The procedures done were: Nephroureterectomy $(n=1)$, Cohen cross trigonal ureteric reimplantation( $n=1)$, Boari flap $(n=1)$, Anderson Hynes dismembered pyeloplasty $(n=1)$, laparoscopy assisted PCNL $(n=1)$ and USG guided double J stenting. The following are the categorized descriptive results of our study (Table 1).

Table 1. The summary of seventeen cases of CRE with the management.

\begin{tabular}{|c|c|c|c|c|c|c|c|c|c|c|c|}
\hline Case & Age/Sex & $\begin{array}{l}\text { Clinical } \\
\text { Profile }\end{array}$ & $\begin{array}{c}\text { Creatinine } \\
\mathrm{mg} / \mathrm{dl}\end{array}$ & Imaging & \begin{tabular}{|c|} 
CROSSED \\
RENAL \\
ECTOPIA
\end{tabular} & FUSION & Kidneys & Ureters & $\begin{array}{l}\text { ASSOCIATED } \\
\text { ANOMALY }\end{array}$ & MANAGEMNET & FOLLOW-UP \\
\hline 1 & $3 \mathrm{~m} /$ Male & \begin{tabular}{|c|} 
Antenatally \\
detected \\
hydronephrosis
\end{tabular} & 0.6 & $\begin{array}{l}\text { USG } \\
\text { IVU } \\
\text { MCU }\end{array}$ & $\begin{array}{c}\begin{array}{c}\text { Left to } \\
\text { right }\end{array} \\
\end{array}$ & Superior & \begin{tabular}{|c|} 
Left gross \\
hydronephrosis \\
Right \\
hydroureteronephrosis
\end{tabular} & $\begin{array}{c}\text { Left atretic } \\
\text { ureter }\end{array}$ & \begin{tabular}{|c|} 
Right grade III \\
VUR \\
Hydrocephalus \\
Meckels \\
Diverticulum
\end{tabular} & \begin{tabular}{|c} 
Left \\
Nephroureterectomy \\
Intestinal resection \\
and anastomosis \\
with Meckels \\
diverticulectomy
\end{tabular} & $\begin{array}{l}\text { USG abdomen } \\
\text { and pelvis, } \\
\text { urine analysis } \\
1 \text { st, quarterly } \\
\text { for year, then } \\
\text { yearly once. }\end{array}$ \\
\hline
\end{tabular}




\begin{tabular}{|c|c|c|c|c|c|c|c|c|c|c|c|}
\hline Case & Age/Sex & $\begin{array}{l}\text { Clinical } \\
\text { Profile }\end{array}$ & $\begin{array}{c}\text { Creatinine } \\
\mathrm{mg} / \mathrm{dl}\end{array}$ & Imaging & \begin{tabular}{|c|} 
CROSSED \\
RENAL \\
ECTOPIA \\
\end{tabular} & FUSION & Kidneys & Ureters & $\begin{array}{c}\text { ASSOCIATED } \\
\text { ANOMALY }\end{array}$ & MANAGEMNET & FOLLOW-UP \\
\hline 2 & 31y/Male & $\begin{array}{l}\text { Recurrent } \\
\text { urinary tract } \\
\text { infection }\end{array}$ & 1.1 & $\begin{array}{l}\text { USG } \\
\text { CECT } \\
\text { MCU }\end{array}$ & $\begin{array}{c}\text { Right to } \\
\text { left }\end{array}$ & $\begin{array}{c}\text { L- } \\
\text { Shaped }\end{array}$ & $\begin{array}{c}\text { Bilateral } \\
\text { hydroureteronephrosis }\end{array}$ & $\begin{array}{l}\text { Bilateral } \\
\text { dilated } \\
\text { ureters }\end{array}$ & $\begin{array}{c}\text { Bilateral Grade } \\
\text { IV VUR }\end{array}$ & $\begin{array}{c}\text { Cohen cross trigonal } \\
\text { reimplantation }\end{array}$ & $\begin{array}{l}\text { USG abdomen } \\
\text { and pelvis, } \\
\text { urine analysis } \\
\text { 1st, quarterly } \\
\text { for year, then } \\
\text { yearly once. } \\
\text { DMSA } \\
\text { scan/MCU 6th } \\
\text { month }\end{array}$ \\
\hline 3 & 17y/Male & $\begin{array}{l}\text { Recurrent } \\
\text { urinary tract } \\
\text { infection }\end{array}$ & 1.0 & $\begin{array}{l}\text { USG } \\
\text { CECT } \\
\text { RGP }\end{array}$ & $\begin{array}{l}\text { Right to } \\
\text { left }\end{array}$ & $\begin{array}{l}\text { Cake/ } \\
\text { lump }\end{array}$ & $\begin{array}{c}\text { Bilateral } \\
\text { hydronephrosis }\end{array}$ & $\begin{array}{c}\text { Left atretic } \\
\text { ureter }\end{array}$ & $\begin{array}{l}\text { Left orifice } \\
\text { hypoplastic }\end{array}$ & $\begin{array}{l}\text { Bridged Boari Flap } \\
\text { (short flap) }\end{array}$ & $\begin{array}{l}\text { USG abdomen } \\
\text { and pelvis, } \\
\text { urine analysis } \\
1 \text { st, quarterly } \\
\text { for year, then } \\
\text { yearly once. }\end{array}$ \\
\hline 4 & 40y/Male & $\begin{array}{c}\text { lower } \\
\text { abdominal } \\
\text { pain, impaired } \\
\text { renal function, } \\
\text { sepsis }\end{array}$ & 4.6 & $\begin{array}{c}\text { USG } \\
\text { NCCT } \\
\text { NEPHROSTOGRAM } \\
\text { RGP }\end{array}$ & $\begin{array}{l}\text { Right to } \\
\text { left }\end{array}$ & $\mid \begin{array}{c}\text { Disc/ } \\
\text { Doughnut }\end{array}$ & $\begin{array}{l}\text { Right mild } \\
\text { hydronephrosis } \\
\text { Left gross } \\
\text { hydronephrosis }\end{array}$ & \begin{tabular}{|c|} 
Bilateral \\
Pelviureteric \\
junction \\
obstruction
\end{tabular} & $\begin{array}{l}\text { Right kidney- } \\
\text { crossing vessel }\end{array}$ & \begin{tabular}{|c|} 
(B/L) Anderson \\
Hynes dismembered \\
pyeloplasty \\
\end{tabular} & \begin{tabular}{|l|} 
USG abdomen \\
and pelvis, \\
urine analysis \\
1st, quarterly \\
for year, then \\
yearly once. \\
\end{tabular} \\
\hline 5 & 50y/Female & Right loin pain & 0.9 & $\begin{array}{l}\text { USG } \\
\text { CECT }\end{array}$ & $\begin{array}{l}\text { Left to } \\
\text { right }\end{array}$ & L- shaped & $\begin{array}{c}\text { Right hydronephrosis } \\
\text { with } 2 \mathrm{~cm} \text { pelvic } \\
\text { calculi }\end{array}$ & Normal & $\begin{array}{l}\text { Renal calculi; } \\
\text { UTI }\end{array}$ & $\begin{array}{l}\text { Laparoscopy } \\
\text { assisted } \\
\text { percutaneous } \\
\text { nephrolithotmy }\end{array}$ & $\begin{array}{l}\text { USG abdomen } \\
\text { and pelvis, } \\
\text { urine analysis } \\
1 \text { st, quarterly } \\
\text { for year, then } \\
\text { yearly once. } \\
\end{array}$ \\
\hline 6 & $10 \mathrm{y} /$ Female & \begin{tabular}{|c|}
$\begin{array}{c}\text { Urinary tract } \\
\text { infection }\end{array}$ \\
\end{tabular} & 1.0 & $\begin{array}{l}\text { USG } \\
\text { CECT }\end{array}$ & $\begin{array}{l}\text { Left to } \\
\text { right }\end{array}$ & $\begin{array}{c}\text { S- } \\
\text { Shaped }\end{array}$ & Normal & Normal & UTI & Antibiotics & $\begin{array}{l}\text { DTPA scan 6th } \\
\text { monthly. }\end{array}$ \\
\hline 7 & $50 \mathrm{y} /$ Female & right loin pain & 1.1 & $\begin{array}{l}\text { USG } \\
\text { CECT }\end{array}$ & $\begin{array}{l}\text { Left to } \\
\text { right }\end{array}$ & $\mid \begin{array}{c}\text { Disc/ } \\
\text { Doughnut }\end{array}$ & Normal & Normal & Nil & Analgesic & $\begin{array}{l}\text { USG abdomen } \\
\text { and pelvis, } \\
\text { urine analysis } \\
1 \text { st, quarterly } \\
\text { for year, then } \\
\text { yearly once. } \\
\end{array}$ \\
\hline 8 & 42y/Male & left loin pain & 1.0 & $\begin{array}{l}\text { USG } \\
\text { CECT }\end{array}$ & $\begin{array}{l}\text { Right to } \\
\text { left }\end{array}$ & L- shaped & Normal & Normal & Nil & Analgesic & $\begin{array}{l}\text { USG abdomen } \\
\text { and pelvis, } \\
\text { urine analysis } \\
6 \text { month for a } \\
\text { year, then } \\
\text { yearly once. } \\
\end{array}$ \\
\hline 9 & $34 \mathrm{y} /$ Female & $\begin{array}{c}\text { Left loin pain } \\
\text { Primigravida } \\
\text { 30wks } \\
\text { gestation }\end{array}$ & 1.2 & $\begin{array}{l}\text { USG } \\
\text { MRI }\end{array}$ & $\begin{array}{l}\text { Right to } \\
\text { left }\end{array}$ & $\mid \begin{array}{c}\text { Disc/ } \\
\text { Doughnut }\end{array}$ & Right hydronephrosis & $\begin{array}{c}\text { Left atretic } \\
\text { ureter }\end{array}$ & $\begin{array}{l}\text { Left } \\
\text { hypoplastic } \\
\text { orifice }\end{array}$ & $\begin{array}{l}\text { Left USG guided } \\
\text { double 'J' stenting }\end{array}$ & $\begin{array}{l}\text { USG abdomen } \\
\text { and pelvis, } \\
\text { urine analysis } \\
6 \text { month for a } \\
\text { year, then } \\
\text { yearly once. } \\
\end{array}$ \\
\hline 10 & 34y/Male & asymptomatic & 1.0 & $\begin{array}{l}\text { USG } \\
\text { NCCT }\end{array}$ & $\begin{array}{l}\text { Left to } \\
\text { right }\end{array}$ & inferior & Normal & Normal & Nil & Regular follow-up & $\begin{array}{l}\text { USG abdomen } \\
\text { and pelvis, } \\
\text { urine analysis } \\
6 \text { month for a } \\
\text { year, then } \\
\text { yearly once. }\end{array}$ \\
\hline 11 & 45y/Male & asymptomatic & 1.0 & $\begin{array}{l}\text { USG } \\
\text { CECT }\end{array}$ & $\begin{array}{l}\text { Left to } \\
\text { right }\end{array}$ & Disc & Normal & Normal & Nil & Regular follow-up & $\begin{array}{l}\text { Post-delivery- } \\
\text { Anderson } \\
\text { Hynes } \\
\text { pyeloplasty. } \\
\end{array}$ \\
\hline 12 & 38y/Male & asymptomatic & 0.9 & $\begin{array}{l}\text { USG } \\
\text { CECT }\end{array}$ & $\begin{array}{l}\text { Right to } \\
\text { left }\end{array}$ & L-shaped & Normal & Normal & Nil & Regular follow-up & $\begin{array}{l}\text { USG abdomen } \\
\text { and pelvis, } \\
\text { Urine analysis } \\
\text { yearly. To } \\
\text { report in case } \\
\text { of pain/ UTI } \\
\end{array}$ \\
\hline 13 & $42 \mathrm{y} /$ Female & $\begin{array}{l}\text { Bleeding per } \\
\text { vagina }\end{array}$ & 1.0 & $\begin{array}{l}\text { USG } \\
\text { NCCT }\end{array}$ & $\begin{array}{l}\text { Left to } \\
\text { right }\end{array}$ & Disc & Normal & Normal & Nil & Regular follow-up & $\begin{array}{l}\text { USG abdomen } \\
\text { and pelvis, } \\
\text { Urine analysis } \\
\text { yearly. To } \\
\text { report in case } \\
\text { of pain/ UTI } \\
\end{array}$ \\
\hline 14 & 41y/Male & asymptomatic & 1.2 & $\begin{array}{l}\text { USG } \\
\text { CECT }\end{array}$ & $\begin{array}{l}\text { Right to } \\
\text { left }\end{array}$ & L-shaped & Normal & Normal & Nil & Regular follow-up & $\begin{array}{l}\text { USG abdomen } \\
\text { and pelvis, } \\
\text { Urine analysis } \\
\text { yearly. To } \\
\text { report in case } \\
\text { of pain/ UTI }\end{array}$ \\
\hline
\end{tabular}




\begin{tabular}{|c|c|c|c|c|c|c|c|c|c|c|c|}
\hline Case & Age/Sex & $\begin{array}{l}\text { Clinical } \\
\text { Profile }\end{array}$ & $\begin{array}{c}\text { Creatinine } \\
\mathrm{mg} / \mathrm{dl}\end{array}$ & Imaging & $\begin{array}{c}\text { CROSSED } \\
\text { RENAL } \\
\text { ECTOPIA }\end{array}$ & FUSION & Kidneys & Ureters & $\begin{array}{c}\text { ASSOCIATED } \\
\text { ANOMALY }\end{array}$ & MANAGEMNET & FOLLOW-UP \\
\hline 15 & $32 \mathrm{y} /$ Female & asymptomatic & 1.1 & $\begin{array}{l}\text { USG } \\
\text { CECT }\end{array}$ & $\begin{array}{l}\text { Left to } \\
\text { right }\end{array}$ & Disc & Normal & Normal & Nil & Regular follow-up & $\begin{array}{l}\text { USG abdomen } \\
\text { and pelvis, } \\
\text { Urine analysis } \\
\text { yearly. To } \\
\text { report in case } \\
\text { of pain/ UTI } \\
\end{array}$ \\
\hline 16 & $36 y /$ Female & asymptomatic & 1.2 & $\begin{array}{l}\text { USG } \\
\text { CECT }\end{array}$ & $\begin{array}{l}\text { Left to } \\
\text { right }\end{array}$ & S- shaped & Normal & Normal & Nil & Regular follow-up & $\begin{array}{l}\text { USG abdomen } \\
\text { and pelvis, } \\
\text { Urine analysis } \\
\text { yearly. To } \\
\text { report in case } \\
\text { of pain/ UTI } \\
\end{array}$ \\
\hline 17 & 39y/Male & asymptomatic & 1.0 & $\begin{array}{l}\text { USG } \\
\text { NCCT }\end{array}$ & $\begin{array}{l}\text { Right to } \\
\text { left }\end{array}$ & L-shaped & Normal & Normal & Nil & Regular follow-up & $\begin{array}{l}\text { USG abdomen } \\
\text { and pelvis, } \\
\text { Urine analysis } \\
\text { yearly. To } \\
\text { report in case } \\
\text { of pain/ UTI }\end{array}$ \\
\hline
\end{tabular}

USG- Ultrasound, IVU-intravenous Urogram, MCU- Micturating Cystogram, CECT- Contrast Enhanced Computed Tomography, RGP-Retrograde Pyelogram

\subsection{Case 1}

A 3-month male child had presented with an antenatal sonogram revealing bilateral hydronephrosis. The child had patent vitellointestinal duct suggestive of Meckels diverticulum and hydrocephalus. Ultrasound (USG) revealed an empty left (L) renal fossa with right (R) hydroureteronephrosis (HUN). Intravenous Urogram (IVU) showed right (R) low placed malrotated kidney, left (L) hydronephrotic unit with atretic ureter (Fig. (1): 1.1,1.2). Micturating cystourethrogram (MCU) showed right grade III reflux. On cystoscopy, right gaping orifice and left orifice hypoplasticity was seen. It was a case of left to right CRE with superior fusion anomaly, where the (L) kidney was placed across the pelvic brim and fused with the (R) kidney at the upper pole. Paediatric surgery opinion was sought for Meckels diverticulum andn hydrocephalous. He underwent extirpation of the left kidney and ureter, intestinal resection and Meckels diverticulectomy. The right grade III VUR was managed conservatively in view of the young age and probability of resolution of reflux as the child attains growth. Hydrocephalous was managed conservatively.

\subsection{Case 2}

A 31 year male with a history of recurrent urinary tract infections (UTI) was being evaluated by department of medicine. The USG demonstrated empty right renal fossa with fused kidneys in the left lumbar region with moderate hydronephrosis. IVU/Contrast Enhanced Computed tomogram (CECT) showed bilateral moderate hydroureteronephrosis with ' $\mathrm{L}$ ' shaped fusion on the left side (Fig. (1): 2.1, 2.2, 2.3,2.4). He was transferred to the department of Urology and MCU was done which revealed bilateral grade IV reflux. The anomaly here was a right to left L-shaped crossed fusion ectopia. He underwent Cohen cross trigonal ureteric reimplantation.

\subsection{Case 3}

A 17year male, with recurrent UTI was admitted for evaluation. USG reported fused kidneys in the pelvis with gross hydronephrosis. CECT Kidney Ureter Bladder (KUB) revealed cake shaped fusion anamoly with atretic left ureter (Fig. (1): 3.1). On cystoscopy, left ureteric orifice was hypolplastic (Fig. (1): 3.3) and retrograde pyelopgram (RGP) / CECT KUB showed (R) solitary ureter crossing to the left side (Fig. (1): 3.2,3.4). It was a case of right to left Cake shaped fusion anomaly with solitary crossed ureter. He was treated with modified pyelovesicosotmy with a short bridge of boari flap.

\subsection{Case 4}

A 40 year man was admitted with dull aching lower abdominal pain, fever and lower abdominal mass. He had impaired renal function with a creatinine of $4.6 \mathrm{mg} / \mathrm{dl}$ and total count ofn 14,500 cells/ $\mu \mathrm{L}$. There were no associated anomalies. On USG and NCCT, he was found to have (R) mildly hydronephrotic kidney fused with (L) grossly hydronephrotic unit (Fig. (2): 4.1, 4.2). He was diagnosed with right to left Disc shaped crossed fusion ectopia with bilateral hydronephrosis. He underwent biateral nephrostomy, the tubes were inserted by the radiologist under ultrasound guidance and he was started on intravenous antibiotics. The creatinine improved from $4.6 \mathrm{mg} / \mathrm{dl}$ to $1.1 \mathrm{mg} / \mathrm{dl}$ over a week with nephrostomy drainage and antibiotics. The renogram was not performed due to financial constraints. Nephrostogram showed bilateral hydronephrosis (left more than right) and bilateral retrograde pyelogram showed 
positive jet sign with features of bilateral PUJ obstruction. He underwent bilateral Pyeloplasty under general anaesthesia. The approach was through the lower midline incision. Intraoperatively, the right kidney was fused to the left unit as a disc shaped fusion with both the pelvis facing anteriorly and hydronephrosis, there was a crossing vessel on the right unit. Hence bilateral Pyeloplasty were performed. The decision for right pyeloplasty was taken due to the presence of a crossing vessel, hydronephrosis on administration of diuretic showing tense pelvis and difficulty in access to the unit at a later date for a repeat surgery due to complex anatomy.
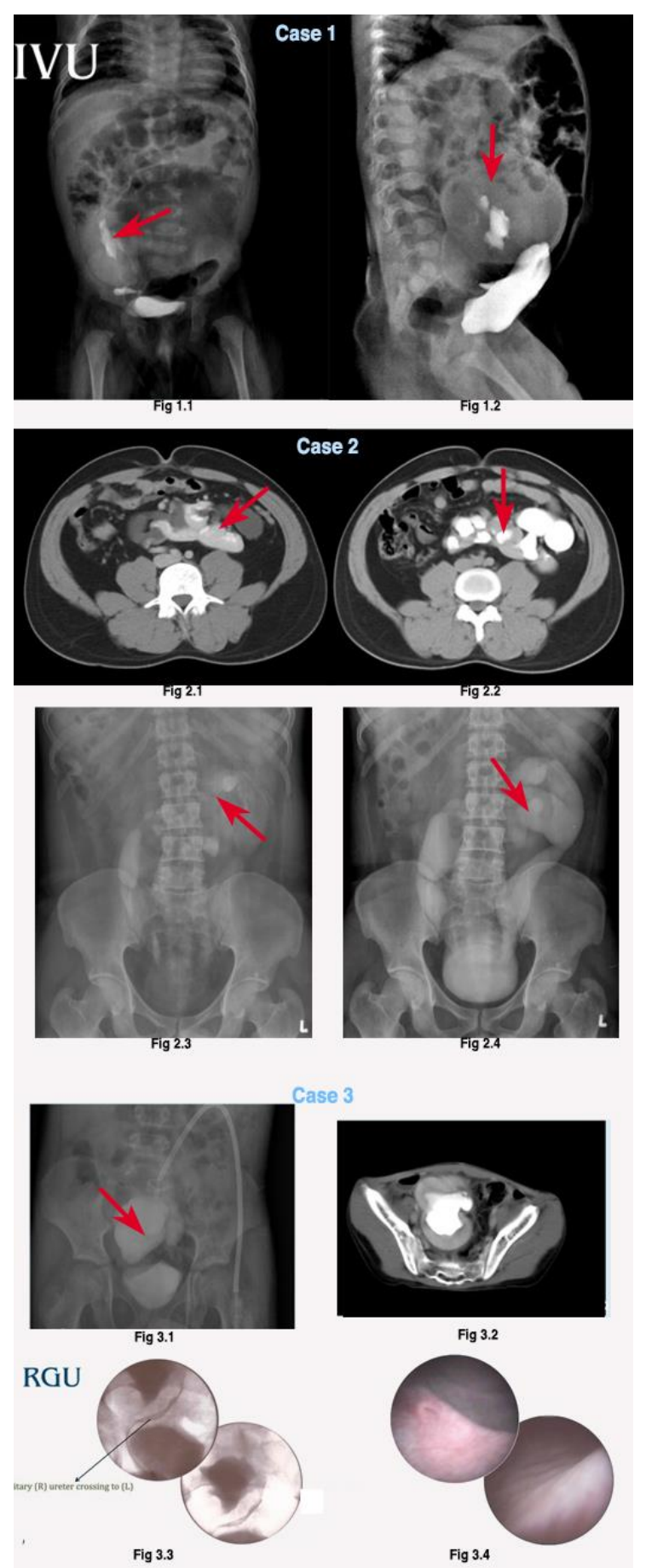

Fig. (1). 1.1,1.2: IVU showing right to left superior ecopia, right hydroureteronephrosis with left hydronephrotic unit with atretic ureter. 2.1, 2.2, 2.3,2.4: IVU/CECT showing bilateral moderate hydroureteronephrosis with right to left ' $L$ ' shaped fusion 3.1,3.2: IVU/CECT KUB revealed a right to left cake shaped fusion. 3.3: RGP showed right solitary ureter crossing to the left side 3.4: On cystoscopy, left hypoplastic ureteric orifice was present. 

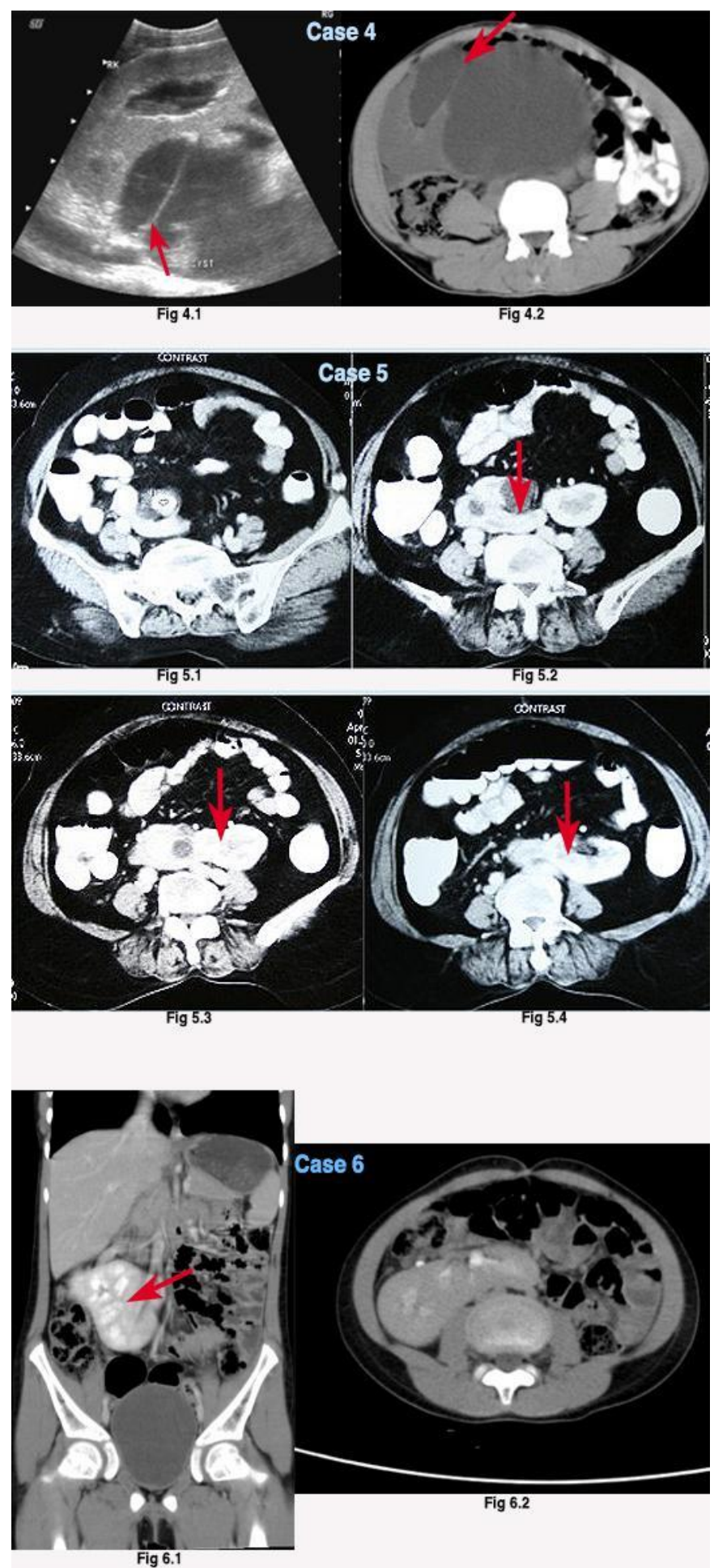

Fig. (2). 4.1, 4.2: USG and CECT showed right to left disc shaped fusion, (R) hydronephrotic kidney fused with (L) grossly hydronephrotic unit. 5.1,5.2,5.3,5.4: CECT KUB showing a left to right crossed L shaped fusion ectopia with a right renal pelvic calculi measuring $2 \mathrm{~cm}$ with $(\mathrm{R})$ unit hydronephrosis. 6.1, 6.2: showed a left to right sigmoid ' $\mathrm{S}$ ' shaped crossed fusion ectopia.

\subsection{Case 5}

A lady in her late 50s presented with right lower abdominal pain. USG showed right hydronephrosis with absent left kidney. CECT KUB reported a left to right $\mathrm{L}$ - shaped crossed fusion ectopia with a right renal pelvic calculi measuring $2 \mathrm{cms}$ with (R) unit hydronephrosis (Fig. (2): 5.1,5.2,5.3,5.4). The stone was removed by laparoscopy assisted percutaneous nephrolithotomy (PCNL). 


\subsection{Case 6}

A 10 year girl presented with four episodes of UTI. Her urine culture showed Escherichia coli with more than $10^{5}$ colony forming units (c.f.u). USG showed right fused CRE. There were no other anomalies. CECT reported a left to right sigmoid ' $\mathrm{S}$ ' shaped crossed fusion ectopia. ((Fig. (2): 6.1, 6.2) She was treated with antibiotics for 5 days. The repeat urine culture was sterile. She was followed with USG of the KUB and urine microscopy every six months for a year, which were normal.

\subsection{Case 7}

A 50 year diabetic, hypertensive lady presented with right loin pain and nausea. There was no past history of lithuria. USG showed left to right fused ectopia with mild pelvicalyceal separation of the right unit. CECT showed left to right CRE with disc shaped fusion; there was no evidence of hydronephrosis or calculi (Fig. (3): 7.1,7.2). She was treated symptomatically with analgesics and antiemetics.
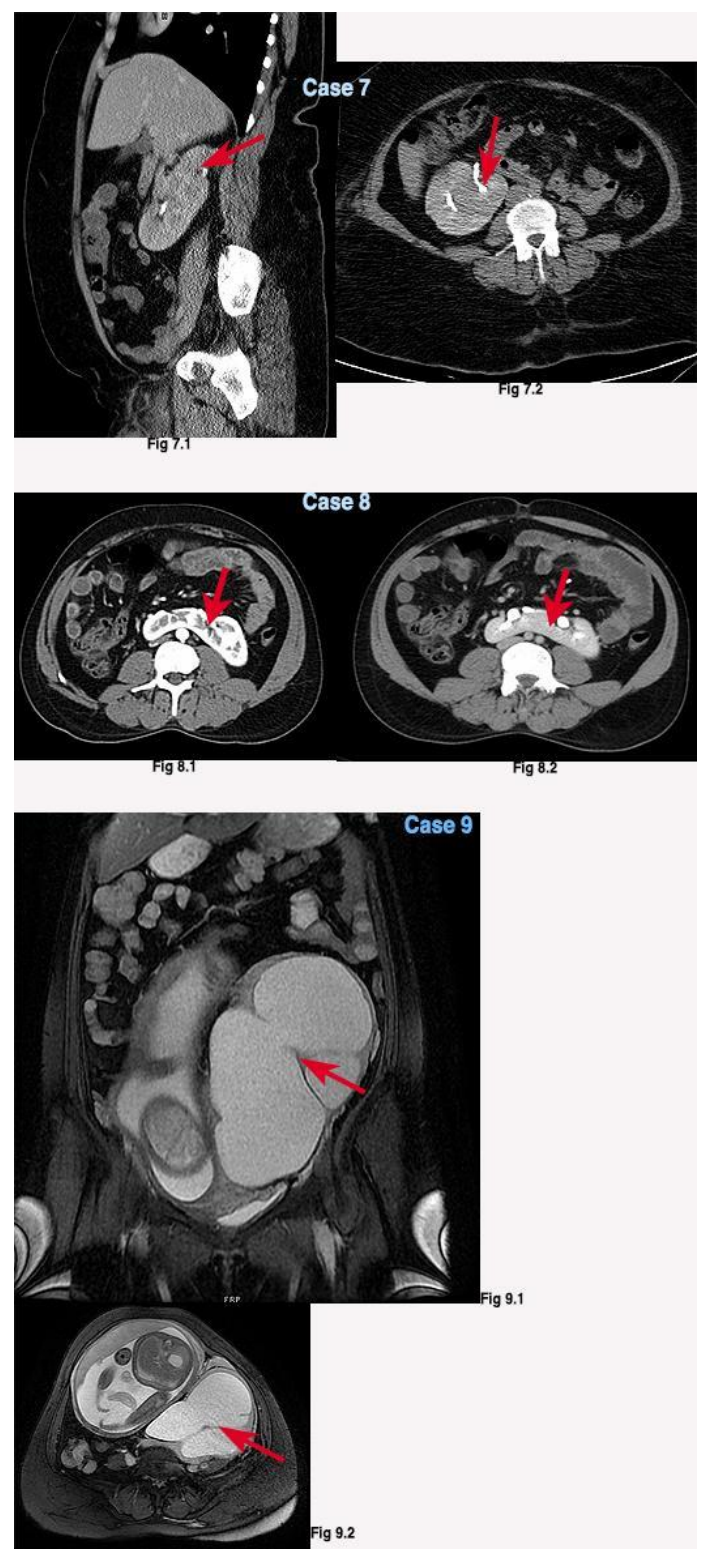

Fig. (3). 7.1,7.2: CECT showed left to right CRE with disc shaped fusion. 8.1,8.2: USG and CECT showed a right to left 'L' shaped crossed fusion with ectopia was present without any abnormality. 9.1, 9.2: MRI showed right to left disc shaped CRE with single ureter, gross hydronephrosis with a gravid uterus and a single live foetus. 


\subsection{Case 8}

An adult male presented with left loin dull aching pain. He was earlier evaluated by an orthopaedician and was treated with muscle relaxants. On USG \& CECT KUB a right to left ' $L$ ' shaped crossed fusion with ectopia was present without any abnormality (Fig. (3): 8.1,8.2). He was treated with analgesics and advised USG/Urine analysis every six months.

\subsection{Case 9}

A 34 year primigravida at 30 weeks period of gestation presented with left loin pain. On USG abdomen, absent right kidney in the renal fossa with left kidney showing gross hydronephrosis and a gravid uterus with single live foetus of 30 weeks of gestation with no anomalies was visualised. Her serum creatinine measured $1.2 \mathrm{mg} / \mathrm{dl} \&$ urea $36 \mathrm{mg} / \mathrm{dl}$. She had proteinuria of 2 grams/day. MRI showed right to left CRE with disc shaped fusion and gross hydronephrosis of the right renal unit with a gravid uterus \& a single live foetus. (Fig. (3): 9.1, 9.2) On cystoscopy there was a right hemitrigone with hypoplastic left ureteric orifice. Under local anaesthesia with USG guidance, right double ' $J$ ' (DJ) ' stenting was done. Her renal parameters improved and she delivered a 2.6 kilogram healthy baby at 37 weeks of gestation. She has been planned for right Anderson Hynes dismembered pyeloplasty.
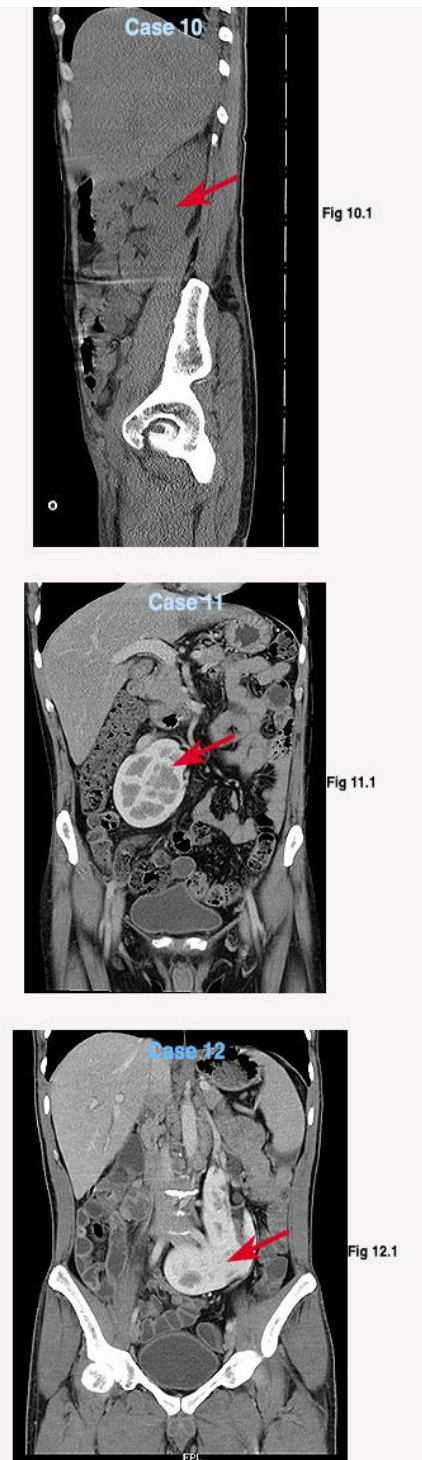

Fig. (4). 10.1: NCCT showed left to right inferior crossed renal ectopia with fusion. 11.1: CECT showed left to right disc shaped fusion anomaly. 12.1: CECT showed right to left $\mathrm{L}$ shaped crossed renal ectopic fusion. 


\subsection{Asymptomatic Cases}

We had $n=8$ asymptomatic cases, who on routine health check-up had incidentally detected crossed fused ectopia of the kidneys. All these patients underwent USG imaging. Three patients were imaged with NCCT ( $\mathrm{n}=3$ ) and remaining $(n=5)$ had a CECT KUB (Figs. 4, 5, 6, 7). These patients were explained regarding the anomaly and the possibility of developing a stone disease/ urinary tract infection in future. Patients were advised yearly USG of the abdomen and pelvis, urine microscopy on follow up. They were asked to seek hospital care, if they noticed symptoms of pain abdomen, UTI, fever or haematuria.
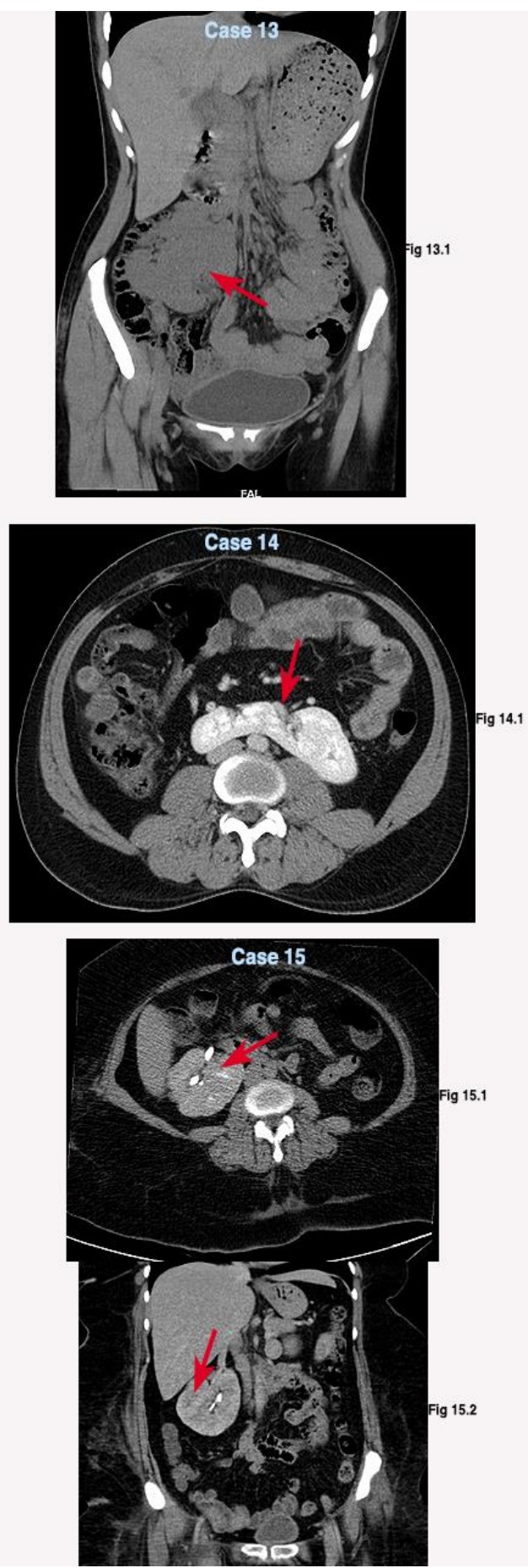

Fig. (5). 13.1: NCCT showed left to right disc shaped CRE with fusion. 14.1: CECT showed right to left L shaped crossed renal ectopia with fusion. 15.1, 15.2: CECT revealed left to right disc shaped fusion anomaly 

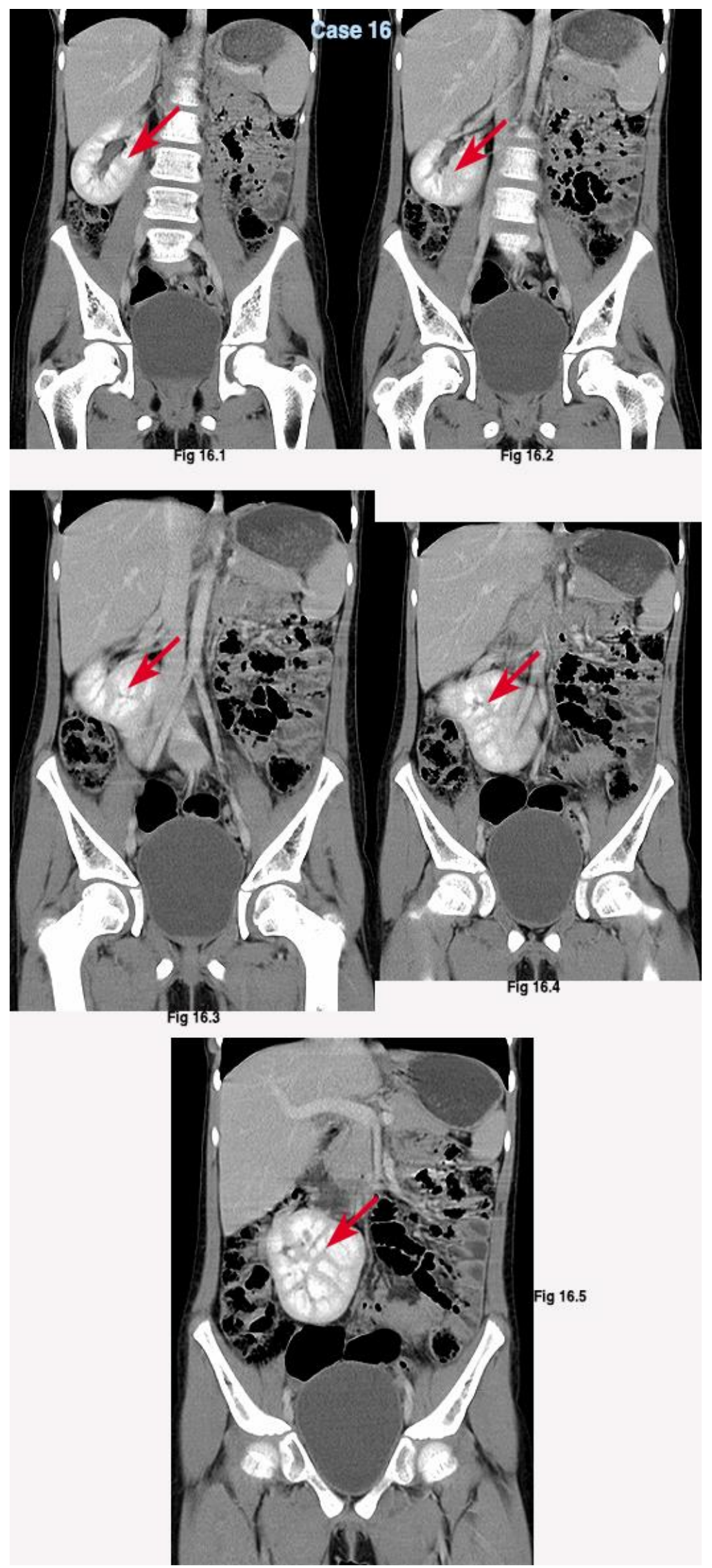

Fig. (6). 16.1,16.2,16.3,16.4,16.5: CECT coronal cuts showed left to right $\mathrm{S}$ shaped crossed renal ectopia with fusion. 


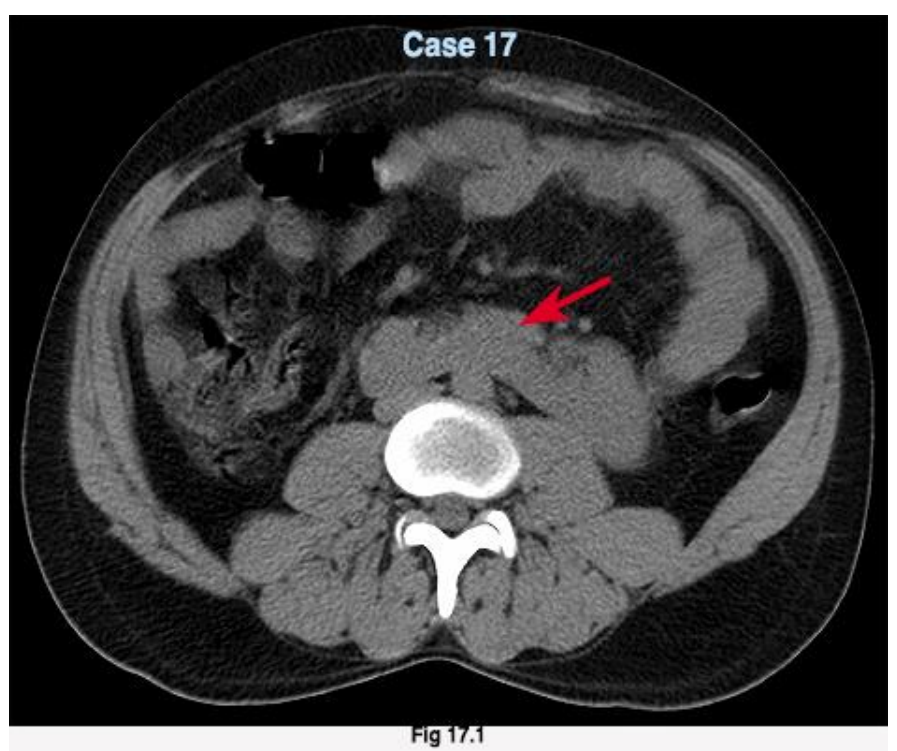

Fig. (7). 17.1: NCCT axial cut showed right to left L shaped crossed renal ectopia with fusion.

\section{DISCUSSION}

The most common renal fusion anomaly is a horseshoe kidney, which accounts for incidence in $0.25 \%$ of the population, or about 1 in 400 persons. Crossed fused renal ectopia (CRE) is the second most common congenital fusion anomaly of kidney [2]. The exact cause of CRE is unknown. Probable explanation for this anomaly as proposed by Wilmer, is due to the crossover that occurs as a result of pressure from abnormally placed umbilical arteries that prevents cephalad migration of the renal unit, which then follows the path of least resistance to the opposite side [3]. The concept behind CRE hinges primarily on the abnormal development \& associated migration of the ureteric bud and metanephric blastema during the $4^{\text {th }}$ to $8^{\text {th }}$ weeks of gestation [4].

Crossed renal ectopia may occur with or without fusion. Around $90 \%$ of the crossed ectopic kidneys are fused to their ipsilateral kidney [5]. The fusion anomalies are categorized by McDonald and McClellan into six different types depending on the type of fusion. They are unilateral fused kidney with inferior ectopia; sigmoid or S-shaped; lump or cake; L-shaped or tandem; disc, shield, or doughnut; and unilateral fused kidneys with superior ectopia [6]. CRE occurs more commonly in males with a ratio of $3: 2$. The left-to-right ectopia is more commonly seen than right to left. CRE with inferior ectopia is the most common variety, whereas fusion with superior ectopia is the least common. The patients in our case series ranged spanned across a 3 month old to a 50 year. The male to female ratio was 9:8. In our series, the Left to Right $(n=9)$ crossed fused ectopia was common. Contrary to the reported cases, L- shaped ( $n=6)$ and Disc shaped $(n=6)$ fusion was most common fusion anomaly seen. Though Inferior ectopia is the commonest fusion anomaly reported in the literature, in our series we had only one case of inferior ectopia $(n=1)$. We had three rare cases of solitary crossed renal ectopia $(\mathrm{n}=3$ ) with fusion (Superior- 1 , Cake shaped=1, Disc shaped=1), with a single ureter. Similar cases were reported by Schwartz et al. and Saha et al. [7, 8].

Most of these cases are asymptomatic and hence go uncharted. CRE is often found incidentally during routine ultrasound screening or at other imaging or during autopsy. They are usually asymptomatic, but may present with vague lower abdominal pain, hematuria, fever, urinary tract infection, hypertension, renal failure, and a palpable abdominal mass [9]. In our case series, most of the patients were asymptomatic $(n=8)$. In symptomatic patients, pain abdomen $(n=5)$ was the most common symptom followed by urinary tract infection $(n=3)$. One patient had presented with urosepsis, impaired renal function and bilateral hydronephrosis, who was stabilised with parenteral antibiotics and nephrostomy to both the units.

Crossed Renal ectopia are associated with abnormalities, which usually involve the ectopic kidney and consists of reflux, cystic dysplasia, ureteropelvic junction obstruction or carcinoma. In all the types of fusion anomalies, the ureteral orifice associated with each kidney is usually orthotopic. A high incidence of other urological abnormalities has been associated with renal ectopy. Vesicoureteral reflux (VUR) is the most common succeeded by other genitourinary tract aberrations such as cryptorchidism, hypospadias, renal multicystic dysplasia \& hydronephrosis. In females, agenesis of the uterus and vagina (e.g, müllerian agenesis and Mayer-Rokitansky-Küster-Hauser syndrome) and 
unicornuate uterus have also been reported. Systemic anomalies include sacral agenesis, imperforate anus, skeletal deformities like scoliosis, cardiovascular and gastrointestinal abnormalities [10]. We encountered three patients with Pelviureteric junction obstruction, one of which had a crossing vessel across pelvi-ureteric junction. Two patients had vesico-ureteric reflux. Three patients had atretic ureter with hypoplastic ureteric orifice. The extra-urogenital anomaly included the presence of Meckels diverticulum and Hydrocephalous. None of these patients had genital or skeletal anomaly, which by far the most common non-urological anomaly associated with CRE.

Initial diagnosis by USG may impart some information regarding associated urinary tract pathology. However anatomic delineation of the CRE with fusion and the functional assessment can best be achieved only by Intravenous urogram, Contrast enhanced computed tomography, Magnetic resonance urogram. Additional assessment by nuclear imaging or retrograde pyelogram may be required for better delineation of the anomaly. Retrograde studies can also be useful for localizing the obstruction when there is insufficient renal function to excrete intravenous contrast. Crossed renal ectopia with fusion are associated with abnormal vascularity [11]. If surgery is contemplated, contrast based CT is needed to characterize vascular anatomy, as the vascular supply can be anomalous to both the ectopic \& non ectopic kidneys. MRI is a useful adjunct when USG and CT scanning are no diagnostic and/or radio contrast media cannot be administered due to allergy or reduced renal function, which increases the risk of contrast-induced nephropathy [12]. Although CECT of the abdomen and pelvis $(n=11)$ was done in most of the patients (symptomatic $n=6$, asymptomatic $\mathrm{n}=5$ ), few patients did not have vascular reconstructed images due to financial constraints. Except for the patient with renal pelvic calculus (Case-5) where PCNL was assisted with laparoscopic guidance, other patients had open reconstruction with due care and diligence to safeguard the abnormally placed vessels to crossed fused kidneys. MRI was done in a pregnant lady with CRE to delineate the anatomy and to avoid radiation exposure.

As is true in patients with horseshoe kidney, most asymptomatic patients have an excellent prognosis without need for intervention. The follow-up protocol for operated patients $(n=6)$ were USG abdomen and pelvis, urine analysis $1^{\text {st }}$, $3^{\text {rd }}$ month for a year, then yearly once. In pelvi-ureteric junction obstruction- DTPA scan $6^{\text {th }}$ monthly, in VUR patient follow up DMSA Scan and MCU. For asymptomatic patients, it was USG abdomen and pelvis with urine analysis every year. Specific instruction was given to visit the emergency room, in case of pain abdomen, fever, UTI or hematuria.

\section{CONCLUSION}

The management of fused kidneys depend on the presentation and functional status of the renal units. Reconstruction of upper or lower tracts is needed in functioning units while non-functioning units need nephrectomy or nephroureterctomy. Any intervention for these anomalous units by open or minimal invasive technique requires care and caution to avoid vascular compromise in functional units with aberrant vasculature.

\section{ETHICS APPROVAL AND CONSENT TO PARTICIPATE}

Not applicable.

\section{HUMAN AND ANIMAL RIGHTS}

Not applicable.

\section{CONSENT FOR PUBLICATION}

Consent for publication obtained.

\section{CONFLICT OF INTEREST}

The authors declare no conflict of interest, financial or otherwise.

\section{ACKNOWLEDGEMENTS}

Declared none.

\section{REFERENCES}

[1] Koff SA, Mutabagani KH. Anomalies of the kidney.Adult and Pediatric Urology. 3rd ed. Philadelphia: Lippincott Williams and Wilkins 2002; p. 2129.

[2] Bauer BS et al. Anomalies of form and fusion, crossed renal ectopia with and without fusion.Wein: Campbell-Walsh Urology Book. 10th ed. Philadelphia: WB Saunders 2012; pp. 3123-360. 
[3] Wilmer HA. Unilateral fused kidney: A report of five cases and a review of the literature. J Urol 1938; 40: 551-71. [http://dx.doi.org/10.1016/S0022-5347(17)71797-1]

[4] Friedland GW, de Vries P. Renal ectopia and fusion. Embryologic Basis. Urology 1975; 5(5): 698-706. [http://dx.doi.org/10.1016/0090-4295(75)90137-5] [PMID: 1129903]

[5] Abeshouse BS, Bhisitkul I. Crossed renal ectopia with and without fusion. Urol Int 1959; 9: 63-91. [http://dx.doi.org/10.1159/000277442] [PMID: 13791482]

[6] McDonald JH, McClellan DS. Crossed renal ectopia. Am J Surg 1957; 93(6): 995-1002. [http://dx.doi.org/10.1016/0002-9610(57)90680-3] [PMID: 13424850]

[7] Schwartz MJ, Bartolotta R, Brill PW, Kovanlikaya A, Hanna M. Pelvic cake kidney with a solitary ureter and bilateral congenital absence of the vas deferens. Urology 2010; 75(1): 170-2. [http://dx.doi.org/10.1016/j.urology.2009.05.031] [PMID: 19628269]

[8] Kaur N, Saha S, Mriglani R, Saini P, Gupta A. Crossed fused renal ectopia with a single ureter: A rare anomaly. Saudi J Kidney Dis Transpl 2013; 24(4): 773-6.

[http://dx.doi.org/10.4103/1319-2442.113881] [PMID: 23816729]

[9] Kelalis PP, Malek RS, Segura JW. Observations on renal ectopia and fusion in children. J Urol 1973; $110(5)$ : 588-92. [http://dx.doi.org/10.1016/S0022-5347(17)60289-1] [PMID: 4750907]

[10] Guarino N, Tadini B, Camardi P, Silvestro L, Lace R, Bianchi M. The incidence of associated urological abnormalities in children with renal ectopia. J Urol 2004; 172(4 Pt 2): 1757-9.

[http://dx.doi.org/10.1097/01.ju.0000138376.93343.74] [PMID: 15371807]

[11] Rubinstein ZJ, Hertz M, Shahin N, Deutsch V. Crossed renal ectopia: Angiographic findings in six cases. AJR Am J Roentgenol 1976; 126(5): 1035-8. [http://dx.doi.org/10.2214/ajr.126.5.1035] [PMID: 178226]

[12] Glodny B, Petersen J, Hofmann KJ, et al. Kidney fusion anomalies revisited: Clinical and radiological analysis of 209 cases of crossed fused ectopia and horseshoe kidney. BJU Int 2009; 103(2): 224-35. [http://dx.doi.org/10.1111/j.1464-410X.2008.07912.x] [PMID: 18710445]

(C) 2018 Hameed et al.

This is an open access article distributed under the terms of the Creative Commons Attribution 4.0 International Public License (CC-BY 4.0), a copy of which is available at: https://creativecommons.org/licenses/by/4.0/legalcode. This license permits unrestricted use, distribution, and reproduction in any medium, provided the original author and source are credited. 